\title{
TGF- $\beta 1$ inhibits the apoptosis of pulmonary arterial smooth muscle cells and contributes to pulmonary vascular medial thickening via the PI3K/Akt pathway
}

\author{
LIMIN LI* ${ }^{*}$ XIAOQIAN ZHANG ${ }^{*}$, XIAOXIA LI, CHENGFANG LV, HONGJUAN YU, \\ MENGYUAN XU, MINGWEN ZHANG, YUEYUE FU, HONGBIN MENG and JIN ZHOU \\ Department of Hematology, The First Affiliated Clinical Hospital of Harbin Medical University, \\ Harbin, Heilongjiang 150001, P.R. China
}

Received March 29, 2015; Accepted October 29, 2015

DOI: $10.3892 / \mathrm{mmr} .2016 .4874$

\begin{abstract}
Previous studies have highlighted that the transforming growth factor- $\beta 1$ (TGF- $\beta 1$ ) pathway may be activated by hypoxic conditions. TGF- $\beta 1$ also participates in the regulation of proliferation, differentiation, migration and apoptosis of various cell types. Furthermore, TGF- $\beta 1$ has been reported to participate in the regulation of the progression of pulmonary arterial hypertension (PAH). However, the effect of TGF- $\beta 1$ on pulmonary arterial smooth muscle cells (PASMCs) and the corresponding molecular mechanisms remain unclear. The present study aimed to determine whether TGF- $\beta 1$ protects against cell apoptosis in PASMCs, and identify the underlying molecular mechanisms. Western blotting, MTT and lactate dehydrogenase activity assays were performed, and the activity of caspase- 3 and caspase- 9 was detected in order to investigate the hypothesis. It was determined that TGF- $\beta 1$ may facilitate cell growth in a dose-dependent manner in serum-starved PASMCs. Furthermore, it was observed that apoptosis in serum-starved PASMCs was inhibited by TGF- $\beta 1$ via regulation of the expression levels of mitochondrial membrane proteins. Additionally, the phosphatidylinositol 3-kinase/protein kinase B (PI3K/Akt) pathway was found to be activated by TGF- $\beta 1$ in PASMCs, while the inhibition of PI3K/Akt signaling also prevented the apoptosis-limiting effects of TGF- $\beta 1$. These observations suggest that TGF- $\beta 1$ protects PASMCs from apoptosis and contributes to pulmonary vascular medial thickening via the PI3K/Akt pathway.
\end{abstract}

Correspondence to: Dr Jin Zhou, Department of Hematology, The First Affiliated Clinical Hospital of Harbin Medical University, 23 Youzheng Street, Harbin, Heilongjiang 150001, P.R. China

E-mail: jinzhou81@126.com

*Contributed equally

Key words: transforming growth factor- $\beta 1$, pulmonary artery smooth muscle cells, phosphatidylinositol 3-kinase/protein kinase B, serum deprivation, apoptosis

\section{Introduction}

As hypoxic pulmonary arterial hypertension (PAH) progresses, the pulmonary vascular resistance and pulmonary arterial pressure increase as a result of pulmonary vessel remodeling (PVR), vasoconstriction, and thrombosis in situ $(1,2)$. The imbalance between cell proliferation and cell apoptosis in pulmonary artery smooth muscle cells (PASMCs) contributes to medial pulmonary vascular hypertrophy, a major pathophysiological change during PVR (3-6). The inhibition of apoptosis and the promotion of cell growth of PASMCs may lead to their overgrowth and result in medial hypertrophy of pulmonary vessels. This may lead to a decrease in the inner-lumen diameter and thus induce increased resistance of pulmonary arteries, which may then elevate the arterial pressure (7).

Transforming growth factor- $\beta$ (TGF- $\beta$ ) triggers numerous cellular responses through various receptors and intracellular transduction pathways (8-10). The members of the TGF- $\beta$ family are multifunctional proteins that are important mediators in pulmonary fibrosis and vascular remodeling (11-13). The three mammalian isoforms of TGF include TGF- $\beta 1$, TGF- $\beta 2$ and TGF- $\beta 3$, and are involved in cell proliferation, differentiation, migration and apoptosis regulation (14). Previous studies have indicated that abnormalities of the TGF- $\beta$ signaling pathway are linked to the pathogenesis of PAH $(12,15,16)$, and that TGF- $\beta 1$ protects against apoptosis of pulmonary artery endothelial cells $(17,18)$. However, the mechanism responsible for the survival of PASMCs and the involvement of TGF- $\beta 1$ in this mechanism remain unclear.

The phosphatidylinositol 3-kinase/protein kinase B (PI3K/Akt) signaling pathway is an important pro-survival pathway. The hyperactivation of Akt may lead to the inhibition of apoptosis in various cell types (19). Growth factors may promote cell proliferation and antagonize cell apoptosis by activating the PI3K/Akt pathway (20). Previous studies have identified that Akt plays an inhibitory role in cell apoptosis by reducing the expression of certain pro-apoptotic proteins (21-23). Additionally, the PI3K/Akt pathway is important in the progression of PAH (24). Therefore, the PI3K/Akt pathway may participate in the growth and survival of PASMCs in response to TGF- $\beta 1$ signaling. 
As there are currently no effective treatment methods for $\mathrm{PAH}$, more research is required in order to explore the molecular mechanisms underlying the progression of $\mathrm{PAH}$, which may help to identify novel treatment methods to interfere with the development of the disease. The present study hypothesized that TGF- $\beta 1$ protects against cell apoptosis in PASMCs via the PI3K/ Akt signaling pathway, resulting in the overgrowth of PASMCs and the medial thickening of the pulmonary artery. The results from the current study demonstrated that TGF- $\beta 1$ inhibits the apoptotic change induced by serum deprivation, and that the inhibitory effects of TGF- $\beta 1$ on cell apoptosis are mediated by the PI3K/Akt signaling pathway. These findings indicate that TGF- $\beta 1$ and its downstream effectors may be potential targets to treat pulmonary artery hypertension.

\section{Materials and methods}

Materials. Recombinant human TGF- $\beta 1$, which was dissolved in deionized water, was obtained from PeproTech, Inc. (Rocky Hill, NJ, USA). Antibodies against Akt (polyclonal; rabbit anti-rat; dilution, 1:1,000; cat. no. 9272), phosphorylated-Akt (monoclonal; rabbit anti-rat; dilution, 1:1,000; cat. no. 4060), and $\beta$-actin (monoclonal; rabbit anti-rat; dilution, 1:1,000; cat. no. 8457) were purchased from Cell Signaling Technology, Inc. (Beverly, MA, USA). Anti- $\alpha$-actin (mouse monoclonal immunoglobulin M; dilution, 1:100; sc-58670) was purchased from Santa Cruz Biotechnology Inc. (Dallas, TX, USA). LY294002 and assay kits used to examine the release of lactate dehydrogenase (LDH), caspase-3 and caspase-9 were purchased from Beyotime Institute of Biotechnology (Haimen, China). Methanol, chloroform, dimethyl sulfoxide, fetal bovine serum (FBS), phosphate buffered saline containing 0.1\% Tween-20 (PBS-T) and bovine serum albumin were purchased from Thermo Fisher Scientific, Inc. (Waltham, MA, USA).

Experimental animals. A total of 6 adult Wistar rats (age, 6 weeks; mean weight, $200 \mathrm{~g}$ ) were obtained from the Experimental Animal Center of Harbin Medical University (Harbin, China). The experimental procedures applied in this study were approved by the Institutional Animal Care and Use Committee of Harbin Medical University. The rats were conditioned at a controlled ambient temperature of $22 \pm 2^{\circ} \mathrm{C}$ with $50 \pm 10 \%$ relative humidity and a $12 \mathrm{~h}$ light-dark cycle (lights on at 8:00 am). All rats were provided with standard chow and water ad libitum.

Cell culture. Rats were sacrificed at 6 weeks of age by cervical dislocation. The outer diameter of pulmonary arteries (distal, 200-500 $\mu \mathrm{m}$ ) was dissected from the lungs of adult Wistar rats under an optical microscope (SZ61; Olympus Corporation, Tokyo, Japan). The extracted segments were cut open, then the adventitia and endothelium of pulmonary arteries were stripped mechanically. PASMCs were dispersed according to previously established methods $(25,26)$. Cells were cultured in Dulbecco's modified Eagle's medium (DMEM) containing $20 \%$ fetal bovine serum in an atmosphere containing $5 \% \mathrm{CO}_{2}$ at $37^{\circ} \mathrm{C}$, in a humidified incubator. Subsequently, anti- $\alpha$-actin was used to determine the purity of the primary cultured PASMCs. The cells of passages 2-3 were used in all the experiments. Serum deprivation was used in order to induce apoptosis in
PASMCs, thus the cells were incubated in DMEM without any serum for $24 \mathrm{~h}$. Cells were divided into three groups: Control, $\mathrm{SD}$, and SD + TGF- $\beta 1$. Cells cultured in complete medium (DMEM $+10 \%$ FBS) were used as the control group. Cells cultured in DMEM without FBS were used as the model of serum deprivation, and cells in the SD + TGF- $\beta 1$ group were serum-deprived and cultured with $10 \mathrm{ng}$ TGF- $\beta 1$ for $24 \mathrm{~h}$.

Quantitative polymerase chain reaction ( $q P C R$ ). In order to determine the mRNA expression levels of B-cell lymphoma 2 (Bcl-2) and Bcl-2-associated X (Bax) in PASMCs obtained from Wistar rats, qPCR was performed. The PASMCs were divided into three groups (Control, SD and SD + TGF- $\beta 1$ ). LY294002 $(10 \mu \mathrm{m})$ was used to block the PI3K/Akt signaling pathway. After $24 \mathrm{~h}$ following treatment, the RNA from $1 \times 10^{6}$ cells from each group was extracted using TRIzol reagent (Invitrogen; Thermo Fisher Scientific, Inc.). Then, reverse transcription was performed to obtain cDNA using a PrimeScript RT Reagent kit (RR037A) from Takara Biotechnology Co., Ltd. (Dalian, China). Reagents used from the kit included $2 \mu 15 \mathrm{X}$ PrimeScript buffer, $0.5 \mu \mathrm{l}$ PrimeScript RT Enzyme Mix I, $0.5 \mu \mathrm{l}$ Oligo dT Primer (50 $\mu \mathrm{M}), 0.5 \mu \mathrm{l}$ Random 6-mers $(100 \mu \mathrm{M}), 500 \mathrm{ng}$ RNA and $10 \mu \mathrm{l}$ RNase Free $\mathrm{dH}_{2} \mathrm{O}$. The reverse transcription thermocycling conditions were as follows: $37^{\circ} \mathrm{C}$ For $15 \mathrm{~min}$ and $85^{\circ} \mathrm{C}$ for $5 \mathrm{sec}$, then stored $4^{\circ} \mathrm{C}$. An Applied Biosystems 7300 Fast Real-Time PCR system (Thermo Fisher Scientific, Inc.) was used to perform all our qPCR experiments and a BLAST program (http://blast.ncbi.nlm.nih.gov/Blast.cgi) was used to confirm the specificity of the primers. The total reaction volume was $20 \mu$ containing: 1x SYBR Premix Ex Taq II (RP820A; Takara Biotechnology Co., Ltd.), $10 \mu \mathrm{M}$ forward and reverse primers, $0.4 \mu \mathrm{l}$ ROX reference dye (Takara Biotechnology Co., Ltd.), and $2 \mu \mathrm{l}$ of cDNA. The qPCR conditions were as follows: $95^{\circ} \mathrm{C}$ for $30 \mathrm{sec} 40$ cycles of $95^{\circ} \mathrm{C}$ for $5 \mathrm{sec}$, and $60^{\circ} \mathrm{C}$ for $31 \mathrm{sec}$, followed by routine melting curve analysis. The sequences of the primers were as follows: Bcl-2 forward, 5'-CGGGAG AACAGGGTATGA-3' and reverse, 5'-CAGGCTGGAAGG AGAAGAT-3' (149 bp); Bax forward, 5'-ATCCACCAAGAA GCTGAG-3' and reverse, 5'-GTAGAAGAGGGCAACCAC-3' (184 bp); and $\beta$-actin forward:5'-AGGCCCCTCTGAACC CTAAG-3' and reverse, 5'-CCAGAGGCATACAGGGAC AAC-3' (118 bp). Relative quantification of target gene expression was calculated using the $2^{-\Delta \Delta \mathrm{Cq}}$ method (27). The ratio of $\mathrm{Bcl}-2 / \mathrm{Bax}$ was then calculated.

Western blot analysis. The cells were cultured in 6 well plates, and $1 \times 10^{6}$ cells were added to each well. Cells were divided into three groups: Control, SD, and SD + TGF- $\beta 1$. Their growth was arrested for $24 \mathrm{~h}$ prior to adding $10 \mathrm{ng}$ TGF- $\beta 1$ under serum deprivation conditions (SD + TGF- $\beta 1$ group). LY294002 (10 $\mu \mathrm{m})$ was used to block the PI3K/Akt signaling pathway. Cells cultured in complete medium were the control group. The cells were then washed three times with ice-cold phosphate-buffered saline, $24 \mathrm{~h}$ after the treatment was applied. Subsequently, the cells were treated with $200 \mu \mathrm{l}$ lysis buffer, containing $50 \mathrm{mM}$ Tris (pH 7.4), $150 \mathrm{mM} \mathrm{NaCl}$, $1 \%$ Triton X-100, $1 \mathrm{mM}$ EDTA and $2 \mathrm{mM}$ PMSF, and then incubated for $30 \mathrm{~min}$ on ice. The lysates were sonicated for $1 \mathrm{~min}$ and centrifuged at $17,000 \mathrm{x} \mathrm{g}$ for $15 \mathrm{~min}$ at $4^{\circ} \mathrm{C}$. The 

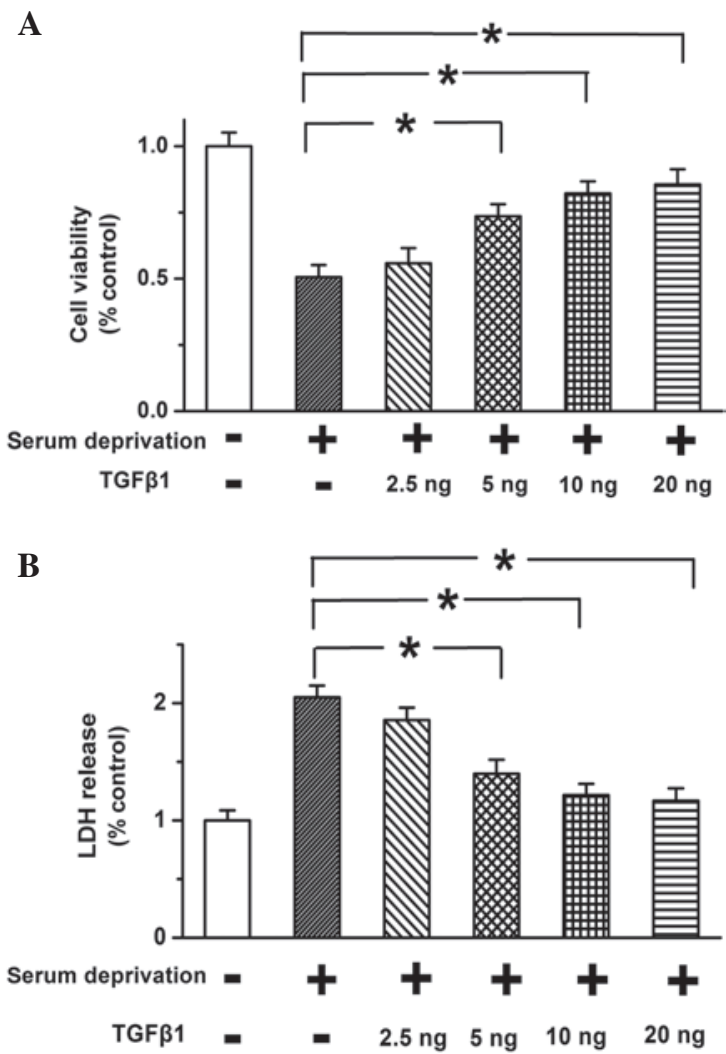

Figure 1. TGF- $\beta 1$ promotes cell growth and inhibits cell death in a dose-dependent manner in serum-starved pulmonary artery smooth muscle cells. (A) Cell viability assay, indicating that cell viability increases with increasing TGF- $\beta 1$ dose. (B) LDH release increased with serum deprivation, and this increase was significantly inhibited by $10 \mathrm{ng}$ TGF- $\beta 1$. Data are represented as the mean \pm standard error of mean. ${ }^{*} \mathrm{P}<0.05(\mathrm{n}=3)$. TGF- $\beta 1$, transforming growth factor- $\beta 1 ; \mathrm{LDH}$, lactate dehydrogenase.

protein concentrations in the supernatant were determined using the Bio-Rad Protein Assay kit (Bio-Rad Laboratories, Inc., Berkeley, CA, USA). The western blot protocol followed to determine the protein expression of the samples was similar to that reported in a previous study (28). Briefly, $50 \mu \mathrm{g}$ protein was electrophoresed on SDS polyacrylamide gels, and then transferred onto polyvinylidene diflfluoride membranes (Merck Millipore, Darmstadt, Germany). Then, 5\% bovine serum albumen was used to block the membrane for $1 \mathrm{~h}$ at room temperature. The membrane was then incubated with phosphorylated-Akt and Akt primary antibodies at $4^{\circ} \mathrm{C}$ overnight. After washing for 35 min with PBS-T, the membrane was incubated with an alkaline phosphatase-conjugated secondary antibody (monoclonal; goat anti-rabbit; dilution, 1:5,000; \#7074; Cell Signaling Technology, Danvers, MA, USA) for $1 \mathrm{~h}$ at room temperature. After washing for $35 \mathrm{~min}$ with PBS-T, immunoreactivity was detected using an enhanced chemiluminescence western blotting detection kit (Amersham Biosciences, Piscataway, NJ, USA) and exposed to X-ray film.

MTT assay. The MTT assay was performed according to the method published by Ma et al (26), in order to determine the cell viability. Briefly, $1 \times 10^{4}$ cells were added to each well in 96-well culture plates and prepared using the same method as used in the western blot analysis. After incubation at $37^{\circ} \mathrm{C}$ for $24 \mathrm{~h}$ following treatment, the cells were incubated for $4 \mathrm{~h}$ in
A

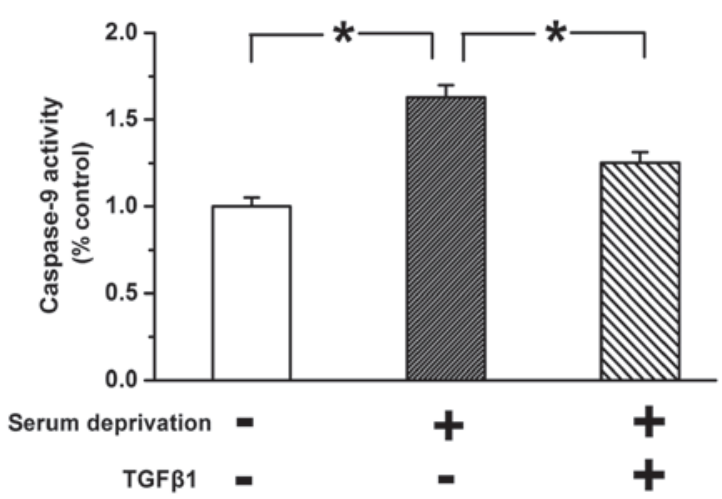

B

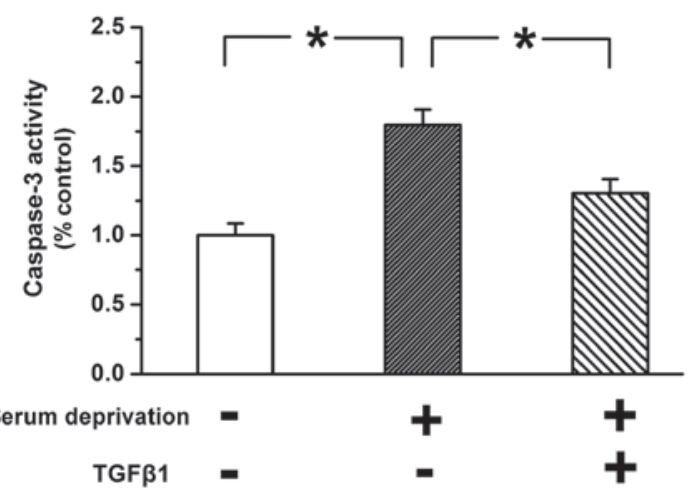

Figure 2. Apoptosis of PASMCs induced by serum deprivation may be inhibited by TGF- $\beta 1$ (10 ng) treatment, as shown by (A) caspase- 9 and (B) caspase-3 activities, which were reduced following the addition of TGF- $\beta 1$. All values are represented as the mean \pm standard error of mean. ${ }^{*} \mathrm{P}<0.05(\mathrm{n}=3)$. TGF- $\beta 1$, transforming growth factor- $\beta 1$; PASMCs, pulmonary artery smooth muscle cells.

0.5\% MTT (Beyotime Institute of Biotechnology). The supernatant was then removed, and $150 \mu 1$ dimethyl sulfoxide was added to each well. The plates were then agitated on a plate shaker for $10 \mathrm{~min}$ at room temperature. A spectrophotometer (Epoch 2; BioTek Instruments, Inc., Winooski, VT, USA) was used to read the absorbance at $490 \mathrm{~nm}$. The measured absorbance value was used to represent the number of living cells.

LDH assay. The expression levels of $\mathrm{LDH}$ were determined using a Cytotoxicity Detection kit (Beyotime Institute of Biotechnology). The experiments were carried out as previous studies (26). Briefly, $100 \mu \mathrm{l}$ culture medium and an equal volume of LDH substrate solution was added to the culture medium for $30 \mathrm{~min}$ at room temperature. The reaction was stopped by adding $0.1 \mathrm{M} \mathrm{NaOH}$ to the mixture, and a spectrophotometer (Epoch 2; BioTek Instruments, Inc.) was used to detect the absorbance at $440 \mathrm{~nm}$.

Caspase- 3 and caspase- 9 activity assay. The cleavage of two chromogenic caspase substrates was determined, including the caspase-3 substrate Ac-DEVD-pNA (also known as $\mathrm{N}$-acetyl-Asp-Glu-Val-Asp p-nitroanilide) and the caspace-9 substrate Ac-LEHD-pNA (also known as $\mathrm{N}$-acetyl-Leu-Glu-His-Asp p-nitroanilide). The experimental procedures followed the manufacturer's protocols and a previously published method (29). Briefly, $50 \mu \mathrm{g}$ total protein was added to $50 \mu 1$ reaction buffer (Beyotime Institute of 
A

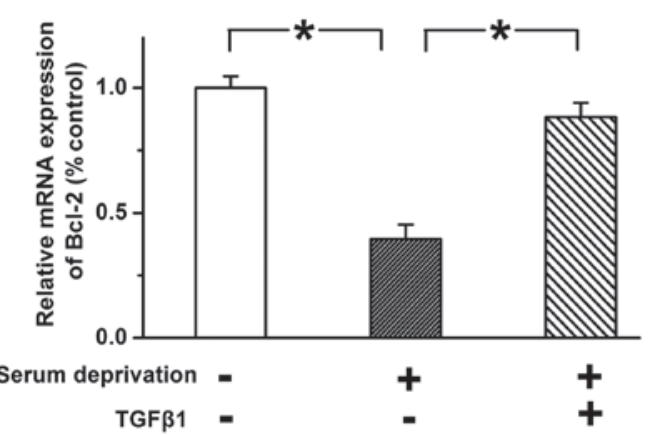

B

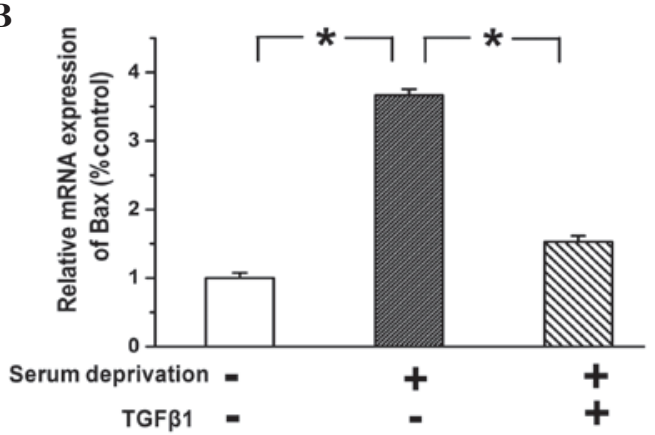

Figure 3. Relative mRNA expression levels of (A) Bcl-2 and (B) Bax in pulmonary arterial smooth muscle cells, determined using quantitative polymerase chain reaction. TGF- $\beta 1$ was found to inhibit cell apoptosis by upregulating the ratio of Bcl-2 to Bax. Serum deprivation inhibited the expression of Bcl-2, and this effect was attenuated by TGF- $\beta 1$. By contrast, serum deprivation enhanced the mRNA expression of Bax, which was reversed upon treatment with TGF- $\beta 1$. All values are denoted as the mean \pm standard error of mean. ${ }^{*} \mathrm{P}<0.05$ ( $\mathrm{n}=3$ ). TGF- $\beta 1$, transforming growth factor- $\beta 1$; Bcl-2, B-cell lymphoma-2; Bax, Bcl2-associated X protein.

A

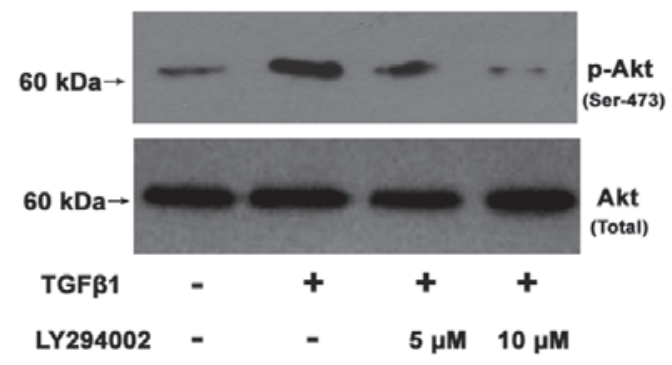

C

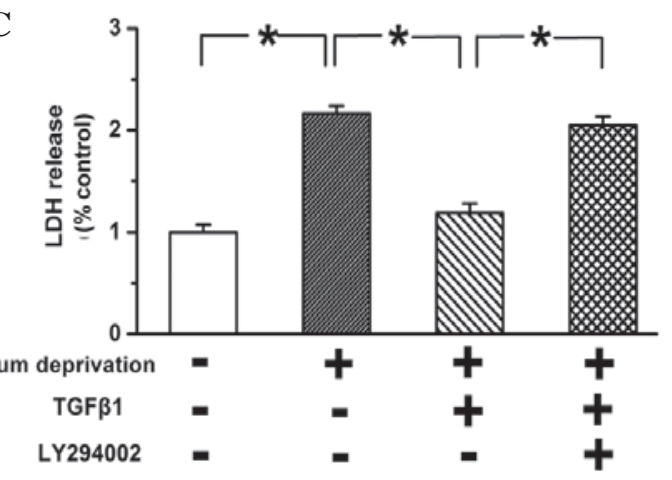

B

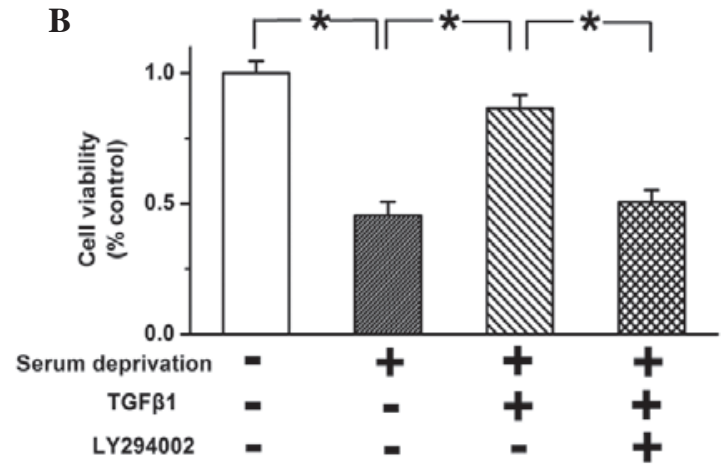

D

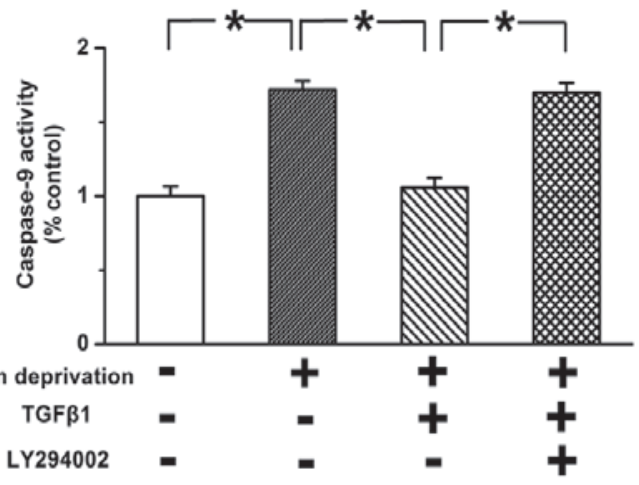

\section{$\mathbf{E}$}

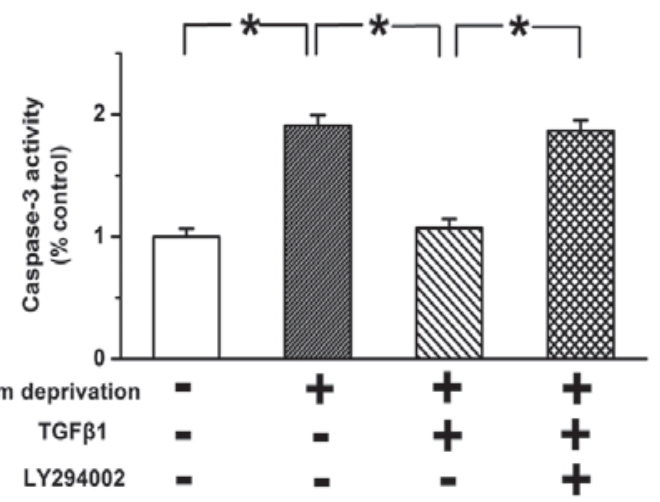

Figure 4. TGF- $\beta 1$ inhibits cell apoptosis by activating the PI3K/Akt pathway in pulmonary artery smooth muscle cells. (A) Western blot analysis, showing that TGF- $\beta 1$ significantly promoted the phosphorylation of Akt, and $10 \mu \mathrm{M}$ LY294002 effectively blocked the activation of the PI3K/Akt pathway. (B) Cell viability assay demonstrated that TGF- $\beta 1$ promoted cell growth by activating the PI3K/Akt pathway. (C) Inhibitory effects of TGF- $\beta 1$ on LDH release were limited following the blocking of the PI3K/Akt pathway. (D) TGF- $\beta 1$-attenuated the activation of caspase- 9 was mediated by the PI3K/Akt pathway. (E) TGF- $\beta 1$ mitigated the activation of caspase-3 via the PI3K/Akt pathway. Data are presented as the mean \pm standard error of mean, ${ }^{*} \mathrm{P}<0.05(\mathrm{n}=3)$. Akt, protein kinase B; p-Akt, phosphorylated-Akt; TGF- $\beta 1$, transforming growth factor- $\beta 1$; LDH, lactate dehydrogenase. 
Biotechnology), which contained $10 \mu 1$ Ac-DEVD-pNA $(2 \mathrm{mM})$ or $10 \mu \mathrm{l}$ Ac-LEHD-pNA $(2 \mathrm{mM})$, and the samples were incubated at $37^{\circ} \mathrm{C}$ for $2 \mathrm{~h}$. The absorbance of yellow pNA cleaved from their corresponding precursors was measured using a spectrophotometer (Epoch 2; BioTek Instruments, Inc.) at $405 \mathrm{~nm}$. The absorbance was used to represent the activity of caspase-3/9.

Statistical analysis. Statistical analysis was performed using SPSS version 15.0 for Windows (SPSS, Inc., Chicago, IL, USA). Experiments were performed in triplicate. All values were represented as the mean \pm standard error of mean. One-way analysis of variance and t-test analysis (two-tailed) were used to determine the statistical significance of differences between the means of different groups. $\mathrm{P}<0.05$ indicated a statistically significant difference.

\section{Results}

TGF- $\beta 1$ promotes the survival of starved PASMCs in a dose-dependent manner. MTT assay was applied to determine the effects of TGF- $\beta 1(10 \mathrm{ng})$ on cell viability of PASMCs. Serum-deprivation was used to induce cell apoptosis. As shown in Fig. 1A, the decrease in cell viability due to serum deprivation was reduced following TGF- $\beta 1$ treatment in a dose-dependent manner. TGF- $\beta 1$ significantly improved cell viability when used at a concentration of $\geq 10 \mathrm{ng}$. The effects of TGF- $\beta 1$ on cell death were also examined, and serum deprivation was found to result in increased release of $\mathrm{LDH}$, which was reversed by the addition of $10 \mathrm{ng}$ TGF- $\beta 1$ (Fig. 1B; $\mathrm{P}<0.05)$. The results suggest that TGF- $\beta 1$ improves cell viability and inhibits cell death in a dose-dependent manner in PASMCs.

TGF- $\beta 1$ inhibits the apoptosis induced by serum deprivation in PASMCs. Caspase- 3 and caspase- 9 are synthesized by the precursor proteins procaspase- 3 and procaspase- 9 , respectively, in response to apoptotic stimuli; subsequently, they are then activated, triggering cell apoptosis (30). Therefore, the activity of caspase- 3 and caspase- 9 was examined to determine whether TGF- $\beta 1$ inhibited the apoptosis of PASMCs. As shown in Fig. 2, the activity of caspase-3 and caspase-9 was significantly greater in untreated serum-deprived cells compared with the control group $(\mathrm{P}<0.05)$. This effect was reversed by treatment with TGF- $\beta 1$ (10 ng), which indicates that TGF- $\beta 1$ inhibits apoptosis induced by serum deprivation.

TGF- $\beta 1$ regulates the expression of mitochondrial membrane proteins to inhibit apoptosis in PASMCs. Bcl-2 and Bax are two important apoptosis-associated proteins, located on the outer membrane of mitochondria. Bcl-2 is an anti-apoptotic protein and Bax is a pro-apoptotic protein. They participate in maintaining mitochondrial integrity and regulating mitochondrial-dependent apoptosis (31). In the present study, TGF- $\beta 1$ was found to inhibit the activation of caspase-9, a key molecular in mitochondrial-dependent apoptosis, and thus the protein expression levels of $\mathrm{Bcl}-2$ and $\mathrm{Bax}$ were examined. The mRNA expression levels of $\mathrm{Bcl}-2$ and $\mathrm{Bax}$ were examined using qPCR. The expression of $\mathrm{Bcl}-2$ was reduced and the expression of Bax was increased in serum-deprived PASMCs compared with the control cells, while treatment with TGF- $\beta 1$ $(10 \mathrm{ng}$ ) reversed these trends (Fig. $3 ; \mathrm{n}=3 ; \mathrm{P}<0.05$ ). These results indicated that TGF- $\beta 1$ inhibits apoptosis by upregulating the expression of $\mathrm{Bcl}-2$ and downregulating the expression of $\mathrm{Bax}$, thus increasing the ratio of $\mathrm{Bcl}-2 / \mathrm{Bax}$.

TGF- $\beta 1$ activates the PI3K/Akt pathway in PASMCs, but the inhibitory effect of TGF- $\beta 1$ on cell apoptosis is abolished following limitation of the PI3K/Akt pathway. The PI3K/Akt pathway is one of the most important survival pathways, and has been reported to always be activated in PASMCs during PAH (32). TGF- $\beta 1$ (10 ng) was found to significantly promote the phosphorylation of Akt compared with the control group (Fig. 4; $\mathrm{P}<0.05)$. LY294002 $(10 \mu \mathrm{M})$ effectively blocked the activation of the PI3K/Akt pathway (Fig. 4A; $n=3 ; \mathrm{P}<0.05$ ). In addition, the pro-survival effects of TGF- $\beta 1$ on PASMCs were weakened following the blocking of the PI3K/Akt pathway (Fig. 4B and C; $\mathrm{n}=3 ; \mathrm{P}<0.05$ ). Caspase- 3 and caspase- 9 activity was not inhibited by TGF- $\beta 1$ when the PI3K/Akt pathway was blocked (Fig. 4D and E; $n=3 ; \mathrm{P}<0.05$ ). These results indicate that TGF- $\beta 1$ inhibits the apoptosis of PASMCs via the PI3K/Akt pathway.

\section{Discussion}

The medial hypertrophy of pulmonary arterial vessels during the progression of PAH is an important pathophysiological change. Previous studies have identified that overgrowth of PASMCs contributes to the hypertrophy of pulmonary vascular media (4-6). The present study provides novel evidence indicating that TGF- $\beta 1$ inhibits the apoptosis of PASMCs through the activation of the PI3K/Akt signaling pathway.

In normal tissues, cell apoptosis is strictly controlled and there is a balance between apoptosis and proliferation. However in pathological conditions, this balance is often disturbed, leading to the overgrowth of cells and the progression of various diseases. PAH is characterized by sustained vasoconstriction, thickening of the pulmonary artery walls and vascular remodeling $(2,33,34)$. Medial wall thickening usually results from the overgrowth of PASMCs, a major medial component of pulmonary vascular vessels. Previous studies have indicated that the increase of cell proliferation and the decrease of cell apoptosis may lead to overgrowth of PASMCs $(14,35)$. This subsequently triggers medial hypertrophy, arterial remodeling and vascular lumen narrowing $(14,35)$. In addition, apoptosis is regarded to play a key role during vascular remodeling $(36,37)$. Therefore, it is necessary to determine the molecular pathway that mediates the inhibitory effects of hypoxia on PASMCs apoptosis, as the findings may provide a novel therapeutic target for future treatments.

Hypoxia is a major trigger of PAH; however, the precise underlying mechanisms are not fully understood. Previous studies have suggested that TGF- $\beta 1$ is activated by hypoxia (3). Furthermore, there is growing evidence that abnormalities in the TGF- $\beta 1$ signaling pathway may be linked to the pathogenesis of PAH $(12,15,16)$. Previous studies have indicated that TGF- $\beta 1$ may participate in the regulation of the development of hypoxic PAH; however, the role of TGF- $\beta 1$ in the survival of PASMCs remains unclear. The current study determined that TGF- $\beta 1$ promotes the survival of PASMCs in a dose-dependent manner 
in starved PASMCs, and TGF- $\beta 1$ inhibits the apoptosis by regulating the expression of mitochondrial membrane proteins. However, the protective effects of TGF- $\beta 1$ were markedly weakened subsequent to the blocking of the PI3K/Akt pathway. Therefore, it is likely that TGF- $\beta 1$ mitigates PASMCs apoptosis and thus promotes pulmonary arterial medial hypertrophy via the PI3K/Akt pathway.

In conclusion, the present study indicates that TGF- $\beta 1$ protects PASMCs from apoptosis by activating the PI3K/Akt signaling pathway, which leads to medial change of pulmonary vessels during the progression of PAH. Notably, the current study determined that the PI3K/Akt pathway mediates the apoptosis-inhibition effect of TGF- $\beta 1$ in the survival of PASMCs and thus offers a novel treatment target for PAH.

\section{Acknowledgements}

This study was supported by a grant from the Youth Science Foundation of Heilongjiang Province (no. QC05C44).

\section{References}

1. Chan SY and Loscalzo J: Pathogenic mechanisms of pulmonary arterial hypertension. J Mol Cell Cardiol 44: 14-30, 2008.

2. Humbert M, Sitbon O and Simonneau G: Treatment of pulmonary arterial hypertension. N Engl J Med 351: 1425-1436, 2004.

3. Archer S and Rich S: Primary pulmonary hypertension: A vascular biology and translational research 'Work in progress'. Circulation 102: 2781-2791, 2000.

4. De Caestecker M and Meyrick B: Bone morphogenetic proteins, genetics and the pathophysiology of primary pulmonary hypertension. Respir Res 2: 193-197, 2001.

5. Stenmark KR and Mecham RP: Cellular and molecular mechanisms of pulmonary vascular remodeling. Annu Rev Physiol 59: 89-144, 1997.

6. Voelkel NF and Tuder RM. Cellular and molecular biology of vascular smooth muscle cells in pulmonary hypertension. Pulm Pharmacol Ther 10: 231-241, 1997.

7. McMurtry MS, Bonnet S, Wu X, Dyck JR, Haromy A, Hashimoto K and Michelakis ED: Dichloroacetate prevents and reverses pulmonary hypertension by inducing pulmonary artery smooth muscle cell apoptosis. Circ Res 95: 830-840, 2004.

8. Derynck R, Zhang Y and Feng XH: Smads: Transcriptional activators of TGF-beta responses. Cell 95: 737-740, 1998.

9. Derynck $R$ and Zhang YE: Smad-dependent and Smad-independent pathways in TGF-beta family signalling. Nature 425: 577-584, 2003.

10. Shi Y and Massagué J: Mechanisms of TGF-beta signaling from cell membrane to the nucleus. Cell 113: 685-700, 2003.

11. Agrotis A, Kalinina N and Bobik A: Transforming growth factor-beta, cell signaling and cardiovascular disorders. Curr Vasc Pharmacol 3: 55-61, 2005.

12. Bartram U and Speer CP: The role of transforming growth factor beta in lung development and disease. Chest 125: 754-765, 2004.

13. Xu YD, Hua J, Mui A, O'Connor R, Grotendorst G and Khalil N: Release of biologically active TGF-betal by alveolar epithelial cells results in pulmonary fibrosis. Am J Physiol Lung Cell Mol Physiol 285: L527-L539, 2003.

14. Rabinovitch M: The mouse through the looking glass: A new door into the pathophysiology of pulmonary hypertension. Circ Res 94: 1001-1004, 2004.

15. Arcot SS, Lipke DW, Gillespie MN and Olson JW: Alterations of growth factor transcripts in rat lungs during development of monocrotaline-induced pulmonary hypertension. Biochem Pharmacol 46: 1086-1091, 1993.

16. Morrell NW, Yang X, Upton PD, Jourdan KB, Morgan N, Sheares KK and Trembath RC: Altered growth responses of pulmonary artery smooth muscle cells from patients with primary pulmonary hypertension to transforming growth factor-beta(1) and bone morphogenetic proteins. Circulation 104: 790-795, 2001
17. Lu Q: Transforming growth factor-betal protects against pulmonary artery endothelial cell apoptosis via ALK5. Am J Physiol Lung Cell Mol Physiol 295: L123-L133, 2008.

18. Mauro M, Kim J, Costello C and Laurence J: Role of transforming growth factor betal in microvascular endothelial cell apoptosis associated with thrombotic thrombocytopenic purpura and hemolytic-uremic syndrome. Am J Hematol 66: 12-22, 2001.

19. Datta SR, Brunet A and Greenberg ME: Cellular survival: A play in three Akts. Genes Dev 13: 2905-2927, 1999.

20. Downward J: Mechanisms and consequences of activation of protein kinase B/Akt. Curr Opin Cell Biol 10: 262-267, 1998.

21. Brunet A, Bonni A, Zigmond MJ, Lin MZ, Juo P, Hu LS, Anderson MJ, Arden KC, Blenis J and Greenberg ME: Akt promotes cell survival by phosphorylating and inhibiting a Forkhead transcription factor. Cell 96: 857-868, 1999.

22. Li Y, Song YH, Mohler J and Delafontaine P: ANG II induces apoptosis of human vascular smooth muscle via extrinsic pathway involving inhibition of Akt phosphorylation and increased FasL expression. Am J Physiol Heart Circ Physiol 290: H2116-H2123, 2006.

23. Wang $X Q$, Sun $P$ and Paller AS: Inhibition of integrin-linked kinase/protein kinase B/Akt signaling: Mechanism for ganglioside-induced apoptosis. J Biol Chem 276: 44504-44511, 2001.

24. Garat CV, Fankell D, Erickson PF, Reusch JEB, Bauer NN, McMurtry IF and Klemm DJ: Platelet-derived growth factor BB induces nuclear export and proteasomal degradation of CREB via phosphatidylinositol 3-kinase/Akt signaling in pulmonary artery smooth muscle cells. Mol Cell Biol 26: 4934-4948, 2006.

25. Zhang L, Ma J, Li Y, Guo L, Ran Y, Liu S, Jiang C and Zhu D: 15-Hydroxyeicosatetraenoic acid (15-HETE) protects pulmonary artery smooth muscle cells against apoptosis via HSP90. Life Sci 87: 223-231, 2010.

26. Ma J, Liang S, Wang Z, Zhang L, Jiang J, Zheng J, Yu L, Zheng $\mathrm{X}$, Wang $\mathrm{R}$ and Zhu D: ROCK pathway participates in the processes that 15-hydroxyeicosatetraenoic acid (15-HETE) mediated the pulmonary vascular remodeling induced by hypoxia in rat. J Cell Physiol 222:82-94, 2010.

27. Livak KJ and Schmittgen TD: Analysis of relative gene expression data using real-time quantitative PCR and the 2(-Delta Delta C(T)) method. Methods 25: 402-408, 2001.

28. Ma J, Zhang L, Han W, Shen T, Ma C, Liu Y, Nie X, Liu M, Ran Y and Zhu D: Activation of JNK/c-Jun is required for the proliferation, survival, and angiogenesis induced by EET in pulmonary artery endothelial cells. J Lipid Res 53: 1093-105, 2012.

29. Wang Z, Tang X, Li Y, Leu C, Guo L, Zheng X and Zhu D: 20-Hydroxyeicosatetraenoic acid inhibits the apoptotic responses in pulmonary artery smooth muscle cells. Eur J Pharmacol 588: 9-17, 2008.

30. Kobayashi T, Masumoto J, Tada T, Nomiyama T, Hongo K and Nakayama J: Prognostic significance of the immunohistochemical staining of cleaved caspase-3, an activated form of caspase-3, in gliomas. Clin Cancer Res 13: 3868-3874, 2007.

31. Adams JM and Cory S: The Bcl-2 protein family: Arbiters of cell survival. Science 281: 1322-1326, 1998.

32. Li L, Xu M, Li X, Lv C, Zhang X, Yu H, Zhang M, Fu Y, Meng H and Zhou J: Platelet-derived growth factor-B (PDGF-B) induced by hypoxia promotes the survival of pulmonary arterial endothelial cells through the PI3K/Akt/Stat3 pathway. Cell Physiol Biochem 35: 441-451, 2015.

33. Mandegar M, Fung YC, Huang W, Remillard CV, Rubin LJ and Yuan JX: Cellular and molecular mechanisms of pulmonary vascular remodeling: Role in the development of pulmonary hypertension. Microvasc Res 68: 75-103, 2004.

34. Pidgeon GP, Tamosiuniene R, Chen G, Leonard I, Belton O, Bradford A and Fitzgerald DJ: Intravascular thrombosis after hypoxia-induced pulmonary hypertension: Regulation by cyclooxygenase-2. Circulation 110: 2701-2707, 2004.

35. Zhang S, Fantozzi I, Tigno DD, Yi ES, Platoshyn O, Thistlethwaite PA, Kriett JM, Yung G, Rubin LJ and Yuan JX: Bone morphogenetic proteins induce apoptosis in human pulmonary vascular smooth muscle cells. Am J Physiol Lung Cell Mol Physiol 285: L740-L754, 2003.

36. Gibbons GH and Dzau VJ: The emerging concept of vascular remodeling. N Engl J Med 330: 1431-1438, 1994.

37. Uhal BD: Apoptosis in lung fibrosis and repair. Chest 122 (Suppl): 293S-298S, 2002. 